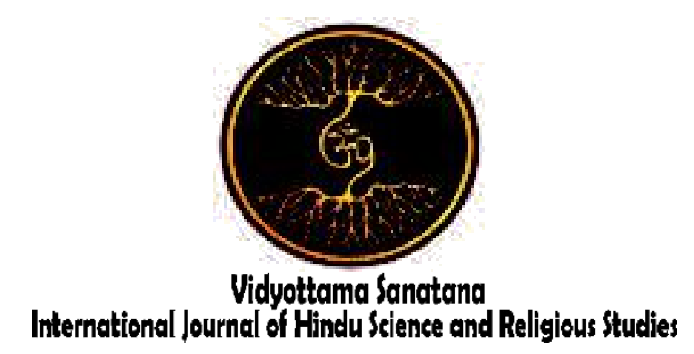

Vol. 3 No. 2 October 2019

\title{
THE IMPLEMENTATION OF THE COMMUNITY BASED TOURISM CONCEPT IN CULTURAL HERITAGE MANAGEMENT AS A TOURIST ATTRACTION IN BATUAN VILLAGE TEMPLE GIANYAR BALI
}

\author{
By: \\ I Wayan Wiwin \\ Udayana University \\ E-mail : wiwinkayoan@gmail.com
}

Received: July 1, 2019

Accepted: September 28, 2019

Published: October 31, 2019

\begin{abstract}
Community-based tourism is the concept of tourism development by prioritizing the active participation of the community with the aim of providing welfare for them while maintaining environmental quality, and protecting their social and cultural life. One of the legacies of Bali's cultural heritage which is also used as a tourist attraction is Batuan Village Temple which is located in Batuan Village, Sukawati District, Gianyar Regency, Bali. This study examines three problems, namely: (1) How is the application of the concept of community-based tourism in managing cultural heritage as a tourist attraction in Batuan Temple?; (2) What factors support the application of the concept of community based tourism in the management of cultural heritage as a tourist attraction in Batuan Village Temple?; and (3) What is the model of community based tourism in cultural heritage management as a tourist attraction in Batuan Village Temple?. This research is a qualitative research method of collecting data through observation, interviews, and documentation. Informants in this study were selected by purposive sampling method. Data analysis was carried out descriptively, qualitatively, and interpretatively.

The results showed that the management of cultural heritage of Batuan Village Temple as a tourist attraction has applied the four principles of community based tourism, those are; the principle of community participation; principles of nature conservation; the principle of the local economy; and socio-cultural conservation principles. The factors that support the application of the concept of community based tourism in Batuan Village include: tourism potential owned by Batuan Village, the aspirations of the villagers of Batuan Village, the synergy among tourism stakeholders in Batuan Village, the support of the Gianyar
\end{abstract}


Regency Government, and social capital owned by villagers of Batuan Village. The management model of Batuan Temple as a pure tourist attraction is managed by the villagers of Batuan Village by applying the principles of community-based tourism in order to achieve common expectations, namely the welfare of the residents of Batuan Village and to realize the sustainable tourism development.

Keywords: Community Based Tourism, Cultural Heritage, Management Of Tourist Attractions.

\section{INTRODUCTION}

Community-based tourism (CBT) is the concept of tourism development by prioritizing active community participation with the aim of providing welfare for them while maintaining environmental quality, and protecting their social and cultural life. The concept of community-based tourism is compatible with sustainable tourism even though the approach is different, where community-based tourism promotes $a$ bottom-up approach, while sustainable tourism puts a top-down approach. The bottom-up approach means that initiatives for tourism development originate from the community, while in the top-down approach, initiatives come from the government. The application of community-based tourism is considered to be able to provide various benefits for the community, namely improving welfare, protecting the environment, and protecting their social and cultural life.

As an international tourism destination, Bali has a variety of natural tourism potentials and cultural that is very interesting for tourists to visit, one of them is Batuan VillageTemple located in Batuan Village, Sukawati District, Gianyar Regency which has a unique cultural heritage in the form of temple buildings and various ancient statues which is always crowded with tourists. It is also because of its very strategic location located in the tourism route of CelukSukawati-Mas-Ubud, which is the excellent choice of fullday tour packages in Bali.

Batuan Village Temple was chosen as the research location because cultural heritage management as a tourist attraction in Batuan Village Temple put forward the concept of community-based tourism (fully managed by local communities). In addition, the selection of this location is also based on the absence of a focused research study on the implementation of the concept of community-based tourism in managing cultural heritage as a tourist attraction in Batuan Village Temple.

Based on the background of the above problems, three problems are formulated, they are: (1) How is the implementation of the concept of community based tourism in cultural heritage management as a tourist attraction in Batuan Village Temple?; (2) What factors support the implementation of the concept of community based tourism in cultural heritage management as a tourist attraction in Batuan Village Temple?; and (3) What is the model of community based tourism in cultural heritage management as a tourist attraction in Batuan Village Temple?.

\section{METHOD}

This research is a qualitative research with the aim of producing a communitybased tourism model in managing cultural heritage as a tourist attraction in Batuan Village Temple. This study describes how the community-based tourism management model for a cultural heritage (Temple) is used as a tourist attraction. The stages of preparing initial data were carried out by identifying the application of the principles of community-based tourism. Observations were carried out on cultural heritage management activities in Batuan Village Temple as a tourist attraction. In addition, information collection that is considered important and relevant to the research is carried out in accordance with the 
formulation of the problem discussed. The method of data collection in this study was carried out through observation, in-depth interviews, and documentation. Informants in this study were selected by purposive sampling method. Data analysis was carried out descriptively, qualitatively, and interpretatively.

\section{RESULT AND DISCUSSION}

a. Development of Tourism Attractions in Batuan Village Temple

In general the temples in Bali, the existence of Batuan Village Temple is Khayangan Desa temple which is worshiped by residents (krama) of Batuan Village, which functions to worship the greatness of God in its manifestation, Village Temple as a place of worship of Lord Brahma as the Creator God in the Tri Murthi concept in the teachings of Hinduism in Bali.

Batuan Village Temple is part of a cultural heritage in Bali which was built in 944 Saka or 1022 AD (Profile of Batuan Village, 2018). This magnificent and artistic temple is located in the Dusun Tengah, Batuan Village, Sukawati District, Gianyar Regency. This tourist attraction is about 16 kilometers to the northeast of the city of Denpasar or about 13 kilometers southwest of Gianyar City.

Along with the development of tourism in Bali, since the 1980s the tourist attraction of Batuan Village Temple continued to develop, therefore besides its main function as a center of worship and traditional activities of local Hindus, this temple was also used as a tourist attraction because of its unique architecture and heritage various ancient objects stored in it, and supported by a very strategic location on the tourist route Batubulan-Celuk-Sukawati-Ubud, then make this temple visited by many tourists.

The attraction of tourists to visit Batuan Village Temple is the very artistic structure of the temple and the carved ornaments on the temple buildings which are very beautiful, which are known for their unique style of stone ornaments. In addition, there are also ancient objects inherited from ancient Bali in the temple area.

Archaeologists from the Center for Cultural Heritage Preservation (BPCB) have conducted research in the Temple, and have discovered ancient relics, such as: phallic emblems, ancient archways, and some ancient building ornaments. Based on these findings, the existence of Batuan Village Temple has been appointed as a cultural preserve by BPCB which is protected by the Law of the Republic of Indonesia Number 5 of 1992 concerning Different Cultural Heritage.

The ancient relics found in Batuan Village Temple have been kept in sacred buildings or pelinggih and there are also other relics placed in groups in one building but still sacred by krama penyungsung of temple.

\section{b. Implementation of the Concept of Community Based Tourism in Cultural Heritage Management as a Tourist Attraction in Batuan Village Temple \\ Community Based Tourism (CBT) is a} concept that emphasizes community empowerment to better understand the values and assets they have, such as culture, customs, culinary cuisine, lifestyle. In the context of tourism development, the community must independently mobilize assets and that value becomes the main attraction for tourist experience. Through the concept of Community Based Tourism, each individual in the community is directed to be part of the tourism economic chain, for which individuals are given the skills to develop a small business.

In managing cultural heritage as a tourist attraction in Batuan Village Temple, it has implemented the basic principles of Community Based Tourism (CBT) development as proposed by UNEP and WTO (2005), namely: (1) Recognizing, supporting and developing community ownership in the tourism industry ; (2) Including community members in starting each aspect; (3) Developing community 
pride; (4) Develop quality of life of community; (5) Ensure environmental sustainability; (6) Maintaining the uniqueness of character and culture in the local area; (7) Helping the development of learning about cultural exchange in the community; (8) Respecting cultural differences and human dignity; (9) Distributing profits fairly to community members; (10) Acting in determining the percentage of income (income distribution) in projects in the community.

Conceptually the basic principle of community-based tourism is to place the community as the main actor through community empowerment in various tourism activities, so that the maximum benefit of tourism is for the community. The main goal of tourism development must improve the welfare of the local community. The concept of Community Based Tourism (CBT) has been implemented in the management of the cultural heritage of Batuan Village Temple to mobilize the local villagers (pekraman village) to actively participate in development as a tourism industry partner. The goal to be achieved is the socioeconomic empowerment of the community itself and putting deeper values in tourism, especially for tourists.

The concept of community based tourism has involved the community of Batuan Pekraman Village in the decisionmaking process, and in obtaining the largest share of income directly from the presence of tourists. Therefore, community-based tourism will be able to create employment opportunities, reduce poverty and bring a positive impact on the preservation of the environment and local indigenous culture which in the end is expected to be able to foster identity and pride from the local population that grows due to increased tourism activities. Community based tourism is a real concept of economics of populism, which is directly implemented by the community and the results can be directly enjoyed by the local community.

Community Based Tourism in Batuan Pekraman Village is not just a tourism business that aims to maximize profits for tourism industry players. Instead, this emphasizes the impact of tourism on society and environmental resources. Community Based Tourism emerged from a community development strategy, using tourism as a tool to strengthen the capabilities of rural community organizations that manage tourism resources with local community participation

Tourism management in Batuan Village is carried out by applying four principles of community-based tourism. These principles are (1) the principle of community participation, (2) principles of nature conservation, (3) local economic principles, and (4) social-cultural conservation principles. The principle of community participation implemented is mainly related to the involvement of villagers of Batuan Pekraman Village to make decisions related to the management of Village Temple and Puseh Temple as tourist attractions. In addition, community participation was also manifested in the ownership of all residents of Batuan Pekraman Village for all available tourist facilities in Batuan Village, participation in management operations, and participation in overseeing tourism management in Batuan Village.

Citizens' ownership makes the welfare of residents of Batuan Pekraman Village increase. In addition, the assets of Batuan Pekraman Village and Village Financial Services of Batuan also increased (Interview with Netra, August 8, 2018). This shows the implementation of local economic principles in managing tourism in Batuan Village. Improving people's welfare contributes to environmental preservation. Before the development of tourism in Batuan Village, residents obtained income from farming, gardening, laborers and craftsmen. After the arrangement of Batuan Village was carried out, the welfare of the people of Batuan Pekraman Village increased, especially greatly assisted in the construction, maintenance, and costs of religious ceremonies at the Khayangan Tiga Temple in Batuan Pekraman Village area which were 
no longer charged to each individuals of krama desa pekraman, but were financed from pekraman village cash funds obtained from the results of tourism management.

The application of the principle of nature conservation can also be seen from the existence of environmental arrangements by making village parks, garden yards and parks around Batuan Village Temple. In addition, zoning is carried out to accommodate several functions of Batuan Village Temple, namely as a religious sanctuary, cultural heritage conservation site, and as a tourist attraction. The application of the principles of nature conservation, especially zoning, supports the application of the principle of social cultural conservation in the management of tourism in Batuan Village.

The application of cultural conservation principles can be seen from the preservation of various archaeological remains in the form of temples, statues, and ancient building ornaments in Batuan Village Temple, as well as the construction of Balinese pavilion (Bale) which can also function as an art show and activities of making upakara for yadnya god's ceremony by local community. Artists and craftsmen appear to entertain visitors and earn income from their appearance. This shows that in addition to contributing to the preservation of traditional Balinese arts, the application of cultural conservation principles has implications for providing additional sources of income for the residents of Batuan Pekraman Village. It also shows a link in the four principles of communitybased tourism in managing tourism in Batuan Village.

\subsection{Factors Supporting the Implementation of the Concept of Community Based Tourism in Managing Cultural Heritage as a Tourist Attraction in Batuan Village Temple}

Based on observations and interviews with relevant parties in the management of the cultural heritage of Batuan Village Temple, the implementation of the concept of community-based tourism in managing cultural heritage as a tourist attraction in Batuan Village Temple is supported by five factors, namely: the tourism potential of the Batuan Village, the aspirations of villagers of Batuan Pekraman Village, the synergy in tourism stakeholders in Batuan Village, the support from the Gianyar Regional Government, and the social capital owned by the residents of Batuan Pekraman Village. The five supporting factors can be explained as follows.

\section{1) Tourism Potential owned by Batuan Pekraman Village}

In addition to the potential attraction of archaeological remains and typical carving architecture of Batuan, Batuan Village also has other tourism potentials that support and open opportunities for local communities to be actively involved and benefit from tourism, for example: the existence of maestros dance, sculpture and art paintings of Batuan that are already well-known to foreign countries, the existence of Rejang Sutri dance as a sacred dance that is only performed on sasih kelima (around November) until sasih kesanga (around March) in Batuan Village Temple, the existence of Gambuh dance clubs, masks and Leather puppets in Banjar Pekandelan, potential of trekking tourism in Banjar Negara, the existence of tourist huts in Banjar Lantangidung, and carving crafts in Banjar Jeleka and sculptures in Banjar Gerih, tourist attractions of traditional Balinese homes and silver craftsmen in Banjar Penida, wooden signboards craftsmen (name plate) in Banjar Bucuan, the existence of Barong Dingkling art in Banjar Tegeha, the existence of Kecak dance art group in Banjar Lantangidung,

2) The villagers aspiration of Batuan Pekraman Village

The community-based tourism development initiative in the management of Batuan Village Temple as a tourist attraction emerged from the leaders of Batuan Pekraman Village. The initiative received support from all residents, so that it became the aspiration of all residents of Batuan 
Pekraman Village. This shows that the arrangement of tourism in Batuan Village is not a policy outlined by the government (topdown), but rather a form of initiative that emerges from the community (bottom-up). Citizens' initiatives are a key characteristic of community-based tourism, because people's aspirations show community participation in the planning phase.

3) Synergy in tourism stakeholders in Batuan Village

Synergy in stakeholders in the management of tourism in Batuan Village is shown by intensive cooperation and communication in the party of Batuan Pekraman Village and headman of Batuan Village, The Institute for Community Empowerment of Batuan Village, and collaboration with the authorized Centre for Cultural Heritage Conservation regarding conservation of archeological objects stored in the Village Temple and Puseh Temple of Batuan Pekraman Village. Communication and cooperation starts from the planning, organizing, implementing, and monitoring stages carried out jointly.

\section{4) Regional Government Support}

The support of the local government, especially the headman of Batuan Village and Tourism Office of Gianyar Regency, is very major in the effort to develop Batuan Village Temple as a tourist attraction, this can be seen from the support of funds allocated by the local government in the form of assistance for the construction of the archaeological hall in Jeroan Pura, granting of assistance fund for the preservation of cultural arts activities and business capital assistance for artisans and art studios in Batuan Village, establishment and counseling of tourism awareness groups, as well as assistance in providing tourism supporting infrastructure and facilities, such as: road repairs and drainage, provision of trash bins and transportation, making village parks, making parking lots, and building public toilet facilities.
5) Social capital owned by villagers of Batuan Pekraman Village

Social capital is a concept that is related to human social life, their connection and their influence on individuals and social structures. Social capital is a factor that if not available will result in a goal that is difficult to achieve.

Bourdieu (1986) defines social capital as a factor that is an accumulation of everything that has been done by someone in his community group. Social capital allows community groups to achieve something (Coleman, 1988; Putnam, 1995). Putnam (1995) also states that social capital encourages people in a society to be willing to engage in collective activities assuming that other members of their community will do the same. Other experts state that social capital promotes coordination and collaboration (Putnam, 1995; Pretty \& Ward, 2001).

The existence of social capital results in community members not doing harmful things, because other people will not do so (Pretty \& Ward, 2001). Social capital consists of several forms. Coleman (1988) states that social capital consists of two things, namely social structure and actors, and is productive. Putnam (1995) states that social capital consists of networks, norms and beliefs between community members. Pretty \& Ward (2001) states that there are 4 forms of social capital, namely trust (relations of trust), reciprocity and exchanges, rules, norms and sanctions (common rules, norms and sanctions), and connectedness, networks and groups connectedness, networks and groups).

Balinese people who are members of traditional villages (pakraman) have a social capital in the form of a welfare system (Meniarta et al, 2009). The forms of social capital of the traditional village community (pekraman village) in Bali consist of values, institutions and mechanisms. The value adopted by indigenous peoples in Bali that all citizens are brothers and sisters (menyama-braya). In addition, happiness and sadness are felt together (joyfully). This 
value is a driving force for indigenous villagers to participate in descent, work together, give each other (ngejot) and social gathering, which is done to redistribute welfare to all indigenous villagers (krama) fairly.

Associated with the development of community-based tourism, the spirit of togetherness that arises from the values, institutions and mechanisms of tradition can generate enthusiasm to work collectively in achieving a common goal. The collective spirit is termed as the "sense of community", that is the quality of interhuman relationship that make them live together in a healthy and sustainable manner (Bopp et al, 2000 in Aref, 2011). Sense of community is able to encourage community participation in tourism development (Aref, 2011).

The implementation of the concept of community-based tourism in the management of Batuan Village Temple is greatly facilitated by social capital owned by the residents of Batuan Pekraman Village. The social capital is in the form of leadership, and villagers trust in traditional leaders, values and norms of menyamabraya (family) and the ups and downs of being residents and paruman/sangkep. The social capital fosters a sense of community (Aref, 2011), and results in villagers being able to realize their shared desire to manage tourism in Batuan Village.

\subsection{Model of Community Based Tourism in Management of Cultural Heritage as a Tourist Attraction in Batuan Village Temple}

The community-based tourism development initiative in the management of Batuan Village as a tourist attraction arose from the public figure of Batuan Pekraman Village. The initiative received support from all residents, therefore it became the aspiration of all residents of Batuan Pekraman Village. This shows that the arrangement of tourism in Batuan Village is not a policy outlined by the Regional Government (top-down), but rather a form of initiative that emerges from the community (bottom-up). Villagers' initiatives are the main characteristics of community-based tourism (Asker et al, 2010; Tasci et al, 2013), because people's aspirations show community participation in the planning stage (Hausler \& Strasdas, 2002).

The villagers' initiative received support from three Institutions in Batuan Village, namely Pekraman Village, headman and Community Empowerment Institute of Batuan Village. The next three institutions formed a structuring committee whose job was to make a structuring plan. Basic information for making plans is obtained from the results of research conducted in collaboration with higher education institutions of tourism in Bali. This shows an effort to collaborate with the world of education. According to Tasci et al (2013) the collaboration is very important to provide support in the form of research results, build citizen awareness and increase the capacity of citizens.

After the arrangement plan was completed, socialization was carried out to get responses from all residents spread across 17 banjar in Batuan Pekraman Village. The socialization shows the support of Batuan Pekraman Village villagers for the arrangement plan. Hausler and Strasdas (2002: 26) state that the model of community involvement in community-based tourism can be in the form of selling products directly to tourists or through intermediaries, inviting investors to open businesses in their area, establishing local tourism businesses, citizens owning and running tourism businesses. This is in accordance with the model presented by Hausler \& Strasdas (2002), stated that citizens own and run a tourism business communally.

The tourism management model in Batuan Village is genuinely managed by pekraman village. Batuan Pekraman Village is the main manager, while the government and tourism industry are partners in managing it. The operational management of tourism in Batuan Pekraman Village was formulated through an agreement on the results of the pekraman community 
consultation in the form of a rule agreement (perarem). Perarem that is carried out by Batuan Pekraman Village in managing tourism in Batuan Village is a reflection of the four principles of community-based tourism implemented. The four principles are the principle of community participation, the principle of nature conservation, the principle of socio-cultural conservation and the principles of the local economy. These principles are in line with the achievement of the three pillars of community-based tourism (Asker et al, 2010). Through the application of rules (perarem) consistenly, it is expected that tourism in Batuan Village can run within the principles of sustainability, therefore its existence can contribute positively to the environment, socio-culture and economic citizenship of Batuan Pekraman Village.

Based on the explanation above, then the application of the concept of communitybased tourism in the management of cultural heritage of Batuan Village Temple can be formulated as a hypothetical model as follows.

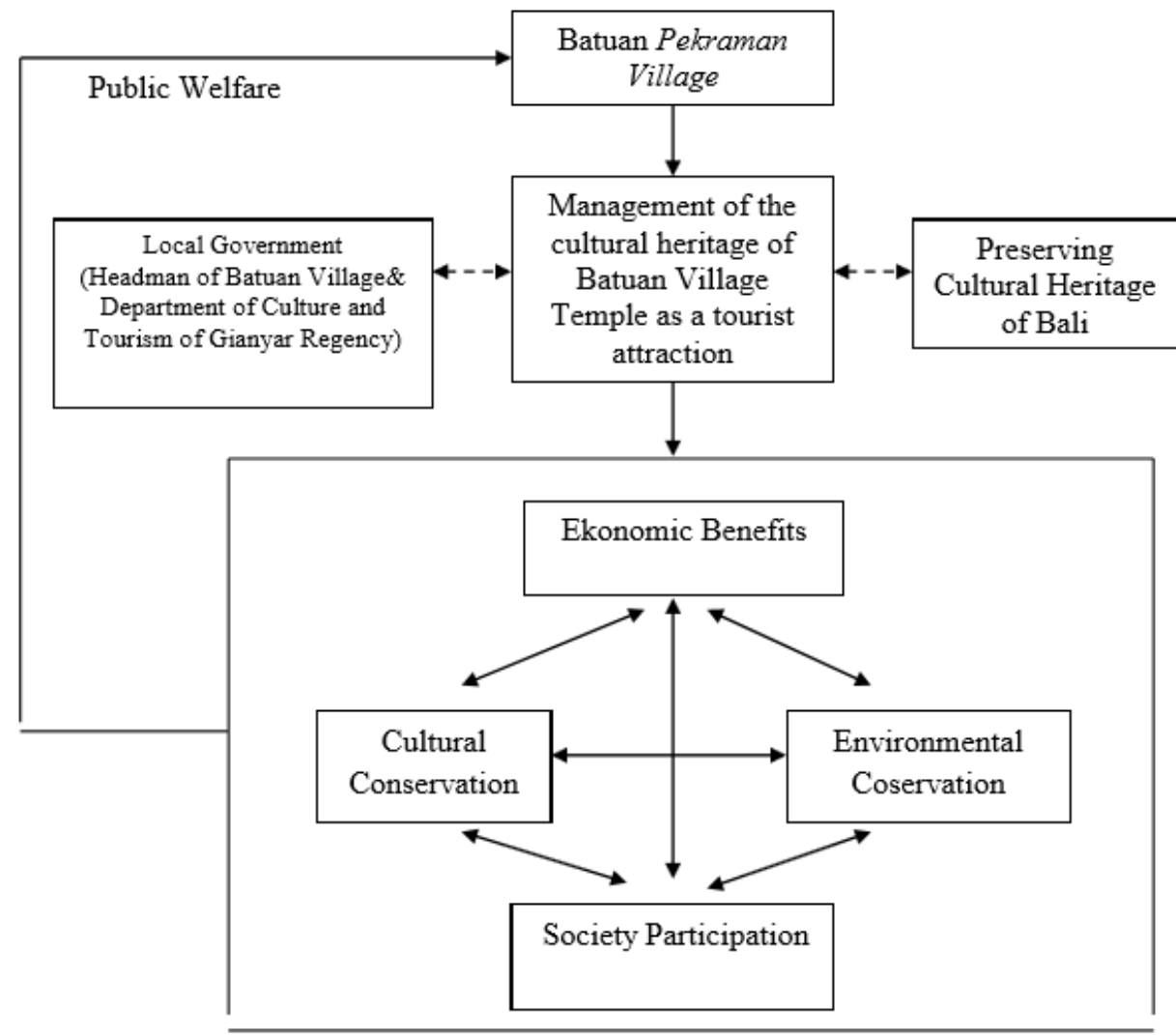

\section{Chart 3.1}

Hypothesis Model of Community Based Tourism in the Management of Cultural Heritage of Batuan Village Temple

The management of Batuan Village Temple as a tourist attraction is purely managed by villagers (krama) of Batuan Pekraman Village, but in the planning, organizing, implementing and monitoring stages always coordinates with related parties such as Headman of Batuan Village, Tourism Office of Gianyar Regency, and Centre for Cultural Heritage Conservation (BPCB) of Bali. The management of the cultural heritage of Batuan Temple is implemented by applying four principles of community-based tourism. Those are the principle of community participation, principles of nature conservation, sociocultural conservation principles and local economic principles in order to achieve common expectations, namely the welfare of community of Batuan Pekraman Village. 
The model of tourism management in Batuan Village can be used as an example for similar tourist attractions that are managed independently by local communities. Community-based tourism as an empowerment approach that involves and places the community as an important actor in the context of the new development paradigm is called sustainable development. Community-based tourism is an opportunity to mobilize all the potential and dynamics of society, to offset the role of large-scale tourism business actors. Community-based tourism does not mean that it is a small and local effort, but needs to be placed in the context of global community cooperation.

\section{CONCLUSION}

Community-based tourism is tourism where the community or local villagers play an important and primary role in making decisions affecting and benefiting their lives and environment. In the concept of community-based tourism contained in is the concept of community empowerment, community empowerment efforts which are in essence always associated with the characteristics of the target as a community that has the characteristics, background, and empowerment of the community. The most important is starting with how to create conditions, or climate that enable the potential of the community to develop. The model of community-based tourism development in Batuan Village has successfully shown that the presence of tourism is able to have a positive impact on the local economies and supports efforts to the preservation of socio-cultural values and environment.

\section{REFERENCES}

Aref, Faiborz. 2011. "Sense of Community and Participation for Tourism Development", Life Science Journal, Volume 8, Issue 1, 2011.

Asker, S., Boronyak, L., Carrard, N., and Paddon, M., 2010. Effective Community Based Tourism, A Best Practice Manual. Singapore:
Sustainable Tourism Cooperative Research.

Bourdieu, Pierre, 1986, "The Forms of Capital", Handbook of Theory of Research for the Sociology of Education, New York: Greenword Press, pp. 46-58.

Chheang, Vannarith. 2011. Angkor Heritage

Tourism and Tourist Perceptions.

International Multidicilinary Journal of Tourism. Volume 6, No. 2: 213240.

Coleman, James S. 1988. "Social Capital in the Creation of Human Capital", American Journal of Sociology, Vol. 94, Supplement: Organizations and Institutions: Sociological and Economic Approaches to the Analysis of Social Structure (1988), pp. S95-S120.

Desa Batuan, 2018. Profil Evaluasi Perkembangan Desa dan Kelurahan. Kantor Perbekel Desa Batuan, Kecamatan Sukawati, Kabupaten Gianyar.

Gunn, Clare A. 1994. Tourism Planning, Basics Concepts Cases. United States Of America: Taylor \& Francis.

Guzman, Lopez (2011). "Community-Based Tourism In Developing Countries, a Case Study". El Salvador.

Hausler, N., Strasdas, W. 2003. Training Manual For Communitybased Tourism, Zschortau: Inwent.

Ife, Jim \& Farnk Tesoriero. 2016. Alternatif Pengembangan Masyarakat di Era Globalisasi. Community Development. Yogyakarta: Pustaka Pelajar.

Keitumetse, Susan O. 2013. Cultural Resources as Sustainability Enablers: Towards a Community-Based Cultural Heritage Resources Management (COBACHREM) Model. Botswana: Okavango Research Institute, University of Botswana

Madiasworo Taufan, Tjahjono Gunawan, Tjahjati Budhy, Budhisantoso Subur. 2014. Sustainable Heritage Area 
Management Model Study on Enviromental Wisdom in Taman Ayun area, Badung Regency, Bali Province. Australian Journal of Basic and Applied Sciences. ISSN: 19918178 pp. 219-225.

Mill, Robert Christie., Morrison, Alastair M. 2012. The Tourism System. United States Of Amerika: Kendall Hunt Publishing Company.

Morrison, Alastair M. 2013. Marketing and Managing Tourism Destinations. London \& New York: Routledge.

Okazaki, Etsuko. 2008. "A CommunityBased Tourism Model: Its Conception and Use", Journal of Sustainable Development, Volume: 16, No. 5, 2008.

Othman, Raja (2011). "Community Capasity Building for Sustainable Tourism Development, Experience From Miso Walay Homestay". Malaysia: Miso Walay Homestay Sabah.

Pearson, M dan Sulivan, S. 1995. Looking after Heritage Place. Melbourne Carlton-Victoria: University Press.

Pretty, Jules N., Ward, Hugh. 2001. Social Capital And The Environment. World Development Vol: 29, No. 2, pp. 209 - 227, 2001 Elsevier Science Ltd.

Putnam, Robert D. 1995. Bowling Alone: America's Declining Social Capital. Journal of Democracy 6:1, Jan 1995, 65-78.

Richardson, John I and Martin Fluker. 2004. Understanding and Managing Tourism. Australia: Pearson Education Australia, NSW Australia.

Satria, Arif, dkk (2005).“Questioning Community Based Coral Reef Management System, Case Study of Awig-Awig in Gili Indah Indonesia".

Tasci, Asli D.A., Semrad, Kelly J. and Yilmaz, Semih S., 2013, Community Based Tourism Finding The Equilibrium in COMCEC Context, Setting the Pathway for the Future. Ankara: COMCEC Coordination Office.
I Timothy, Dallen J. 2011. Cultural Heritage and Tourism: An Introduction. Amazon.com

Tzanakis, Michael. 2013. Social capital in Bourdieu's, Coleman's and Putnam's theory: empirical evidence and emergent measurement issues. Educate, Vol. 13, No. 2, 2013, p. 223.

World Heritage Unit. 1985. Australia's World Heritage. Canberra: Department of Environment, Sports and Territories. 